\title{
The role of catchment characteristics in determining surface water nitrogen in four upland regions in the UK
}

\author{
R.C. Helliwell ${ }^{1}$, M.C. Coull ${ }^{1}$, J.J.L. Davies², C.D. Evans ${ }^{3}$, D. Norris ${ }^{3}$, R.C. Ferrier ${ }^{1}$, \\ A. Jenkins ${ }^{2}$ and B. Reynolds ${ }^{3}$ \\ ${ }^{1}$ Macaulay Institute, Craigiebuckler, Aberdeen, AB15 8QH, UK \\ ${ }^{2}$ Centre for Ecology and Hydrology, Wallingford, Oxfordshire, OX10 8BB, UK \\ ${ }^{3}$ Centre for Ecology and Hydrology, Bangor, Gwynedd, LL57 2UP, UK \\ Email for corresponding author: r.helliwell@macaulay.ac.uk
}

\begin{abstract}
Hydrochemical and catchment data from 80 upland moorland sites in four regions with contrasting climate, soils, geology and geomorphology have been analysed to assess the key catchment attributes that influence enhanced leaching of soluble nitrogen to surface waters. The regions are the South Pennines of northern England, the Snowdonia National Park in north Wales, the Galloway region of south-west Scotland and the Mourne Mountains in Northern Ireland, all highly acidified, with median $\mathrm{pH}$ values of $<5.5$. Linear regression of mean summer and winter concentrations for nitrate $\left(\mathrm{NO}_{3}^{-}\right)$, ammonium $\left(\mathrm{NH}_{4}^{+}\right)$, dissolved organic nitrogen (DON) and dissolved organic carbon (DOC) were expressed as functions of catchment attributes. Nitrate concentrations in waters draining catchments dominated by peaty soils (large $\mathrm{C}$ pool) were much less than those in catchments dominated by mineral soils (small $\mathrm{C}$ pool). Hence, if future $\mathrm{N}$ deposition levels are maintained or increase, high-altitude catchments with small carbon pools are potentially more susceptible to $\mathrm{NO}_{3}^{-}$leaching. All $\mathrm{N}$ species exhibit seasonality; this is most marked in Galloway and least marked in the South Pennines, which implies that the South Pennines have reached an advanced stage of $\mathrm{N}$ saturation. Surface water inorganic $\mathrm{N}$ concentrations and the ratio of dissolved organic carbon (DOC) to dissolved organic $\mathrm{N}$ (DON) can be related to deposition inputs, although relationships differ throughout the year. If the DOC/DON ratio is indicative of catchment $\mathrm{N}$ saturation, levels of $\mathrm{N}$ retention are at least partially determined by deposition levels. This study identifies $\mathrm{N}$ deposition as a major interregional control on the degree of catchment $\mathrm{N}$ saturation and on $\mathrm{N}$ leaching to surface waters; it stresses the importance of catchment factors in modifying the relationship between $\mathrm{N}$ deposition and leaching in acid sensitive UK upland catchments.
\end{abstract}

Keywords: seasonal nitrogen deposition and leaching; catchment characteristics, South Pennines, Snowdonia; Galloway, Mourne Mountains

\section{Introduction}

While sulphur (S) emissions and deposition continue to decline in the UK in response to internationally agreed emission control protocols (Second S protocol and MultiPollutant Multi-Effect Gothenburg Protocol, UNECE 2002), there is increasing concern regarding the relative role of nitrogen $(\mathrm{N})$ emissions to total anthropogenic loadings to terrestrial and aquatic ecosystems (Curtis et al., 2005). Unlike sulphur, concentrations of nitrogen in deposition have not changed substantially in 20 years, except in some upland regions where a slight increase has been detected (Fowler et al., 2005; Vincent et al., 1997).

Atmospheric deposition is an important source of $\mathrm{N}$ in semi-natural upland ecosystems. Nitrogen is generally tightly cycled and retained in these ecosystems with minimal release to surface water or ground water. However, there is concern that current atmospheric inputs of $\mathrm{N}$ may exceed the retention capacity of soils and biota, resulting in disruption of the nitrogen cycle and nitrogen 'saturation' (Curtis et al., 2005; Evans and Jenkins, 2000; Evans et al., 2000; Stoddard, 1994). Milne and Hartley (2001) have proposed that enhanced leaching may have a significant effect on terrestrial and aquatic eutrophication and biodiversity. The contribution of $\mathrm{NH}_{4}^{+}$to total inorganic $\mathrm{N}$ losses is generally negligible in semi-natural systems implying uptake, adsorption or nitrification of $\mathrm{NH}_{4}^{+}$, resulting in the dominance of $\mathrm{NO}_{3}^{-}$in inorganic $\mathrm{N}$ leaching (Chapman and Edwards, 1999; Davies et al., 2005). Recent 
studies have highlighted the importance of the $\mathrm{N}$ status relative to carbon $(\mathrm{C})$ availability in the upper soil layers as an indicator of $\mathrm{N}$ leakage in forested systems (Gundersen et al., 1998; Kristensen et al., 2004; Lovett et al., 2002). Analyses of catchment-scale soil and runoff chemistry in moorland ecosystems, however, fail to produce such a relationship. Hence, either different processes dominate the $\mathrm{N}$ cycle or factors such as the total catchment $\mathrm{C}$ pool are important in these systems (Evans et al., 2005).

Although numerous studies of semi-natural ecosystems in Europe and the north-eastern United States have demonstrated positive relationships between surface water $\mathrm{NO}_{3}{ }^{-}$concentrations and atmospheric $\mathrm{N}$ deposition (Allott et al., 1995; Curtis et al., 1998; Harriman et al., 1998), this relationship can vary significantly between neighbouring catchments (Kernan and Allott, 1999) and between areas with similar $\mathrm{N}$ deposition inputs (Curtis et al., 1998; Kamenik et al., 2001). For instance, factors such as climate, geology, geomorphology, soil type and land use were identified as important descriptors of surface water $\mathrm{N}$ concentration in these studies. The factors that influence surface water $\mathrm{N}$ in moorland ecosystems, however, are poorly understood due to complex process interactions governing the terrestrial catchment response to $\mathrm{N}$ deposition.

This study shows how catchment characteristics and the processes governing catchment response to $\mathrm{N}$ deposition influence surface-water nitrogen and carbon concentrations in four acidified regions in the UK namely the South Pennines, Snowdonia, Galloway and the Mourne Mountains.

\section{Methods}

\section{INTRODUCTION TO THE REGIONS STUDIED}

This regional assessment is focussed on standing waters in upland regions with broadly similar $\mathrm{N}$ deposition fluxes, contrasting climate, geomorphology, soils and geology, but similar sensitivity to acidification as defined by their current exceedance of surface water critical loads (NEGTAP, 2001). Standing waters (lakes) were selected in preference to streams because their hydrochemistry is less variable over annual time periods (NEGTAP, 2001). In the Galloway region, the surface waters of significant interest are naturally formed, shallow upland lakes (lochs) $(n=17)$. Small mountain lakes $(n=25)$ were selected in Snowdonia, whilst in the South Pennines where there are no natural lakes, reservoirs were the dominant water bodies $(n=30)$. A combination of reservoirs $(n=2)$ and naturally formed lakes (loughs) $(n=6)$ were sampled in the Mournes region (Fig. 1).

The South Pennine region in Northern England receives the highest median N deposition for the period 1999-2001

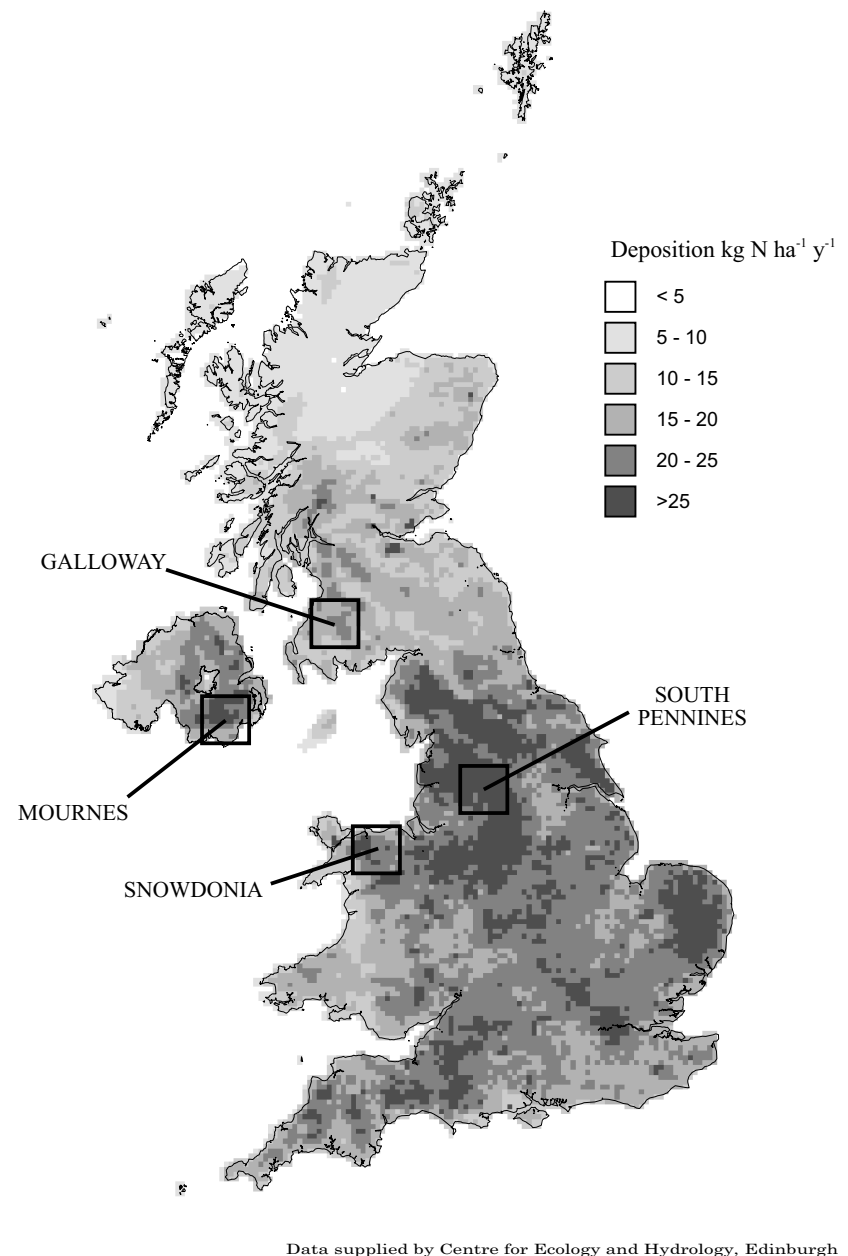

Fig. 1. Total median $N$ deposition $\left(\mathrm{kg} \mathrm{N} \mathrm{ha-}^{-1} \mathrm{yr}^{-1}\right)$ from 1999 to 2001 and location of the study regions in the UK.

(28 $\mathrm{kg} \mathrm{N} \mathrm{ha}^{-1} \mathrm{yr}^{-1}$ ) and is the most heavily acidified region, whilst the Mourne mountains, Snowdonia and Galloway receive less $\mathrm{N}$ deposition $\left(22,18,19 \mathrm{~kg} \mathrm{~N} \mathrm{ha}^{-1} \mathrm{yr}^{-1}\right.$ respectively). Rainfall is influenced strongly by the geographic position of the regions and, as expected, the mountainous regions to the north and west (Galloway $2127 \mathrm{~mm}$, Snowdonia $1902 \mathrm{~mm}$ and the Mournes $1714 \mathrm{~mm}$ ) receive higher rainfall than the South Pennine region to the east $(1107 \mathrm{~mm})$. Although rainfall estimates are annual means from 1999-2001, this calculated rainfall is very similar to the annual measured rainfall from 2002 (i.e. rainfall at Eskdalemuir, Galloway, for 2002 totalled $2079 \mathrm{~mm}$ ). The location of the regions and proximity to major industrial centres results in an inverse relationship between rainfall and total nitrogen deposition (Table 1).

Geomorphological characteristics vary among the four regions (Table 1). The Snowdonia catchments are fairly heterogeneous; around half are located in deeply incised 


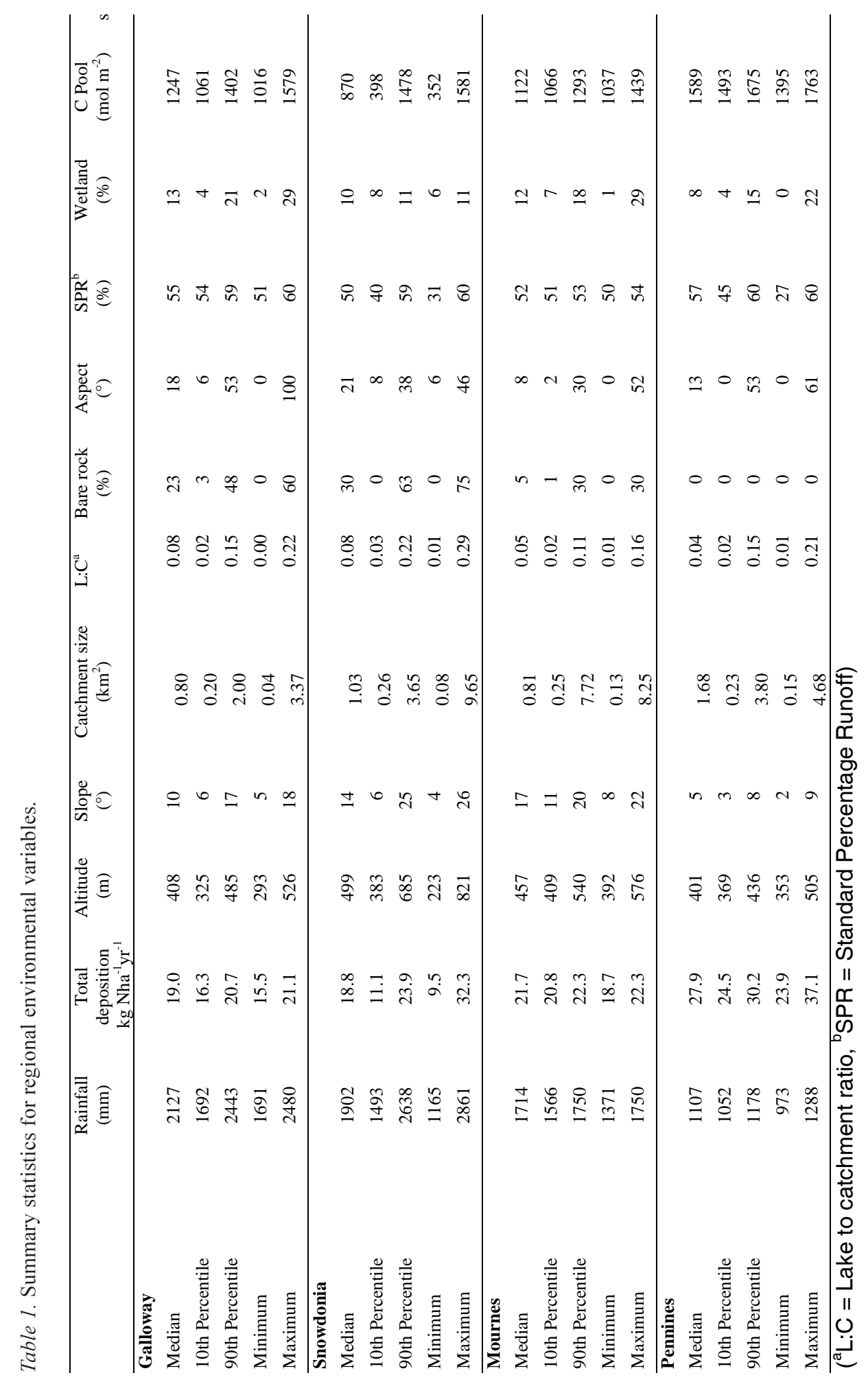


corries, with large areas of bare rock and scree and generally thin, patchy soils. The remainder includes high-elevation plateau lakes draining a mixture of bare rock, thin soils and deeper peats; lower-elevation lakes draining moderately steep, acid grassland catchments, with more extensive mineral soils; and a small number of lakes draining blanket peats. Overall, soils are predominantly peaty podzols, peaty rankers and deep peats. Large areas of bare rock $(23 \%)$ also feature in the Galloway region although the mountain topography is less severe with gentler slopes with highaltitude catchments nestling on mountain plateaux (Table 1). Soils in this region are typically organic, with $49 \%$ of sites covered by peaty podzols and peaty gleys and a further $37 \%$ by blanket and valley peat. The terrain of the Mourne Mountains is dominated by rock rankers on steep slopes and isolated scattered rocks, organo-mineral soils and peat on more gentle gradients. In contrast, sites in the South Pennine region are characterised by high altitude, gently undulating topography, which is covered by blanket peat (74\%), grading to peaty podzols, peaty gleys $(21 \%)$ and brown earths (4\%) at lower elevations. Generally, all soil types identified in this study are thin, organic-rich and acidic, and offer only a limited ability to neutralise acid deposition. The median regional altitude ranged from $\sim 400 \mathrm{~m}$ in the South Pennines to $\sim 500 \mathrm{~m}$ in Snowdonia. All upland regions are dominated by semi-natural vegetation including heather and dwarf shrub heathland (Calluna), acid grassland (Molinia, Nardus and Eriophorum), blanket bog vegetation (Sphagnum) and montane vegetation. Heather/acid grassland/bog vegetation is sustained largely by low intensity sheep grazing. Since the focus of this study was on $\mathrm{N}$ cycling in moorland systems, lakes draining forested areas were not sampled.

The sensitivity of surface water to acidic deposition in these regions is associated mainly with the characteristics of their underlying geologies. The granitic bedrock typical of the higher elevations in Galloway and the Mournes is resistant to weathering and so provides a relatively low supply of base cations to buffer acidic deposition. Snowdonia is geologically complex, mainly of Ordovician sedimentary formations of Cambrian and Silurian rocks. These geological assemblages are sensitive to acid deposition, offering little or no buffering capacity (e.g. acid igneous rocks), although some of the intermediate igneous rocks and the Ordovician shales are less sensitive (Kernan and Allott, 1999). This is also true in the South Pennines where Millstone Grit of Carboniferous age is extremely low in base cations; coal measures occur mainly to the east and west of the region (Evans et al., 2000).

\section{SAMPLING METHODOLOGY}

To identify the importance of catchment attributes on seasonal $\mathrm{N}$ dynamics, surface waters were sampled in February, May, August and November 2002. Where possible, the outflow of each water body was sampled.

Samples were stored at $4{ }^{\circ} \mathrm{C}$ prior to analysis at the Centre for Ecology and Hydrology and the Macaulay Institute. Alkalinity (Metrohm automatic titrator) and $\mathrm{pH}$ (Radiometer $\mathrm{pH}$ meter) were determined on unfiltered samples: the remainder of the sample was then syringe filtered $(0.45 \mu \mathrm{m}$ cellulose acetate filters) and analysed for conductivity (Model P335 conductivity meter); base cations (PerkinElmer 3300 Dual View inductively coupled plasma optical emission spectroscopy); $\mathrm{SO}_{4}, \mathrm{NO}_{3}$ and chloride (Dionex Ion Chromatograph); ammonium $\left(\mathrm{NH}_{4}\right)$ and silicon (Technico Auto Analyser II system); total dissolved N (Thermalox N analyzer using thermal oxidation); and dissolved organic carbon (DOC) (Thermalox carbon analyser). All methods followed strict quality control procedures and the analytical laboratories regularly take part in the external quality assurance network AQUACHECK (Aquacheck Ltd, Manchester). Dissolved organic N (DON) was calculated as the difference between total dissolved and dissolved inorganic $\mathrm{N}$ concentrations. Since all samples were filtered, particulate $\mathrm{N}$ and therefore total $\mathrm{N}$ are not reported. Acid neutralising capacity was calculated as the sum of base cations minus the sum of acid anions, and $\mathrm{xSO}_{4}$ as total $\mathrm{SO}_{4}$ minus marine $\mathrm{SO}_{4}$, determined as chloride concentration (in $\mu$ eq $\mathrm{l}^{-1}$ ) multiplied by 0.104 , the ratio of $\mathrm{SO}_{4}$ to chloride in sea salt.

In each region, organic soil samples were taken from three sites that represented (a) a range of inorganic $\mathrm{N}$ in the surface waters, and (b) major soil-type characteristics of the region. Six organic soil samples were taken from the soil surface $(0-10 \mathrm{~cm})$ at each site, with three from freely drained areas and three from flushed areas. In addition, full profile descriptions and chemical and physical characteristics of the soils were determined for all major soil types. These data were used to calculate a catchment weighted soil base saturation (BS\%) using a methodology reported by Helliwell et al. (1998). Sampling procedures and analytical protocols were consistent between regions.

\section{SPATIAL DATA ARCHIVES}

Catchments were characterised according to a number of physical and chemical attributes that were hypothesised to influence surface water $\mathrm{N}$ concentrations. Where possible, catchment attributes were derived from national datasets to allow statistical comparison of individual regions. 
Geomorphic properties: Catchment boundaries, lake areas, slope, and altitude estimates were generated from a $50 \mathrm{~m} \times 50 \mathrm{~m}$ resolution digital elevation model (DEM). The catchment boundaries of some sites in the South Pennine region were digitised manually since this region has been subjected to significant engineering works to divert water supplies. The aspect, or more specifically, the proportion of a catchment facing north, north-east and north-west was also determined from the DEM.

Rainfall and deposition inputs: Measuring rainfall and atmospheric deposition in mountainous terrain is difficult. Rainfall and $\mathrm{N}$ deposition (corrected for orographic enhancement) were therefore calculated from 1999-2001 deposition data provided by the Centre for Ecology and Hydrology, at a $5 \mathrm{~km} \times 5 \mathrm{~km}$ grid scale. A mean value was calculated for each catchment by averaging the values for the relevant grids and proportioning the deposition from partial grids. At a national scale, Fowler et al. (2005), identified a statistically significant relationship between annual rainfall and concentrations of $\mathrm{NO}_{3}{ }^{-}$and $\mathrm{NH}_{4}{ }^{+}$ions in deposition; with concentration declining as precipitation increases.

Hydrological properties: Estimates of standard percentage runoff (SPR), an indication of a soil's hydrological response, were derived from the HOST (Hydrology of Soil Types) classification (Boorman et al., 1995). Low SPR values signify freely drained soils, while higher values represent soils with impeded drainage. A topographic index value $(\ln (a / \tan b))$ was calculated for every cell in a catchment (where ' $a$ ' is the upslope area contributing flow to cell, determined by surface topography, and ' $b$ ' is the slope angle of the cell), to indicate the relative tendency of soil within each cell to become saturated; the higher the value of this index, the greater tendency for saturation. By integrating this information with land cover and soil information within a GIS, an estimate of saturated/wetland area was derived for all sites (Table 1).

Biophysical Properties: The area of bare rock was derived from soil maps, memoirs and photographs for each region except Snowdonia where values were determined by remote sensing and aerial photographs. For the purposes of statistical analyses, the soils were divided into mineral and peaty soils. The area of mineral soil was represented by poorly developed rankers and alpine soils, and peaty soils by soils mapped with a peaty descriptor from the SSLRC 1:250 000 soil maps for Snowdonia and the South Pennines, the OSNI 1:50 000 map of the Mournes and the Macaulay Institute 1:63 360 map for Galloway. For statistical purposes, regionally distinct geology was grouped according to the Skokloster classification (Nilsson and Grennfelt, 1988) and weathering rates were weighted by occurrence of classes within each catchment (Table 1). Two main land-cover types were identified in the analysis, namely semi-natural grassland and heather moorland. As heather moorland frequently correlates with areas of peaty soils, only the area of grassland was included in the regression models to avoid statistical co-linearity issues.

Carbon Pool Estimates: 1282 organic soil records of percentage carbon, loss on ignition, soil texture were sorted by slope and divided into eight classes. The average percentage carbon in each class was used to calculate a $\mathrm{C}$ pool with the total measured organic soil depth and bulk density determined by pedo-transfer functions (A. Lilly, pers. comm.). Within a GIS, slope information was generated from a site DEM and the number of $50 \mathrm{~m}^{2}$ grids in each slope class were used to calculate a weighted $\mathrm{C}$ pool for the catchments.

\section{STATISTICAL ANALYSIS}

Analysis of variance (ANOVA) was used to assess interregional differences in water chemistry. Linear regressions were calculated to test the relationship between catchment attributes and surface water $\mathrm{N}$ and DOC concentrations. For regression analyses reported in the text and Table 2, asterisks (i.e. ${ }^{*},{ }^{* *}$ and ${ }^{* *}$ ) correspond to significance levels of 0.05 , 0.01 , and 0.001 respectively and the preceding ' + ' and ' - ' signs indicate positive and negative relationships in the data. Stepwise multiple linear regression ('best subset') analysis was used to explore inter-relationships between a number of catchment characteristics and surface water $\mathrm{N}$ and DOC concentrations (Helsel and Hirsch, 1991). The terms selected from the best subset procedure are used in the multiple regression models and a partial $\mathrm{F}$ test is performed on each term as a final test of the power of the model. Only the independent variables with $p$-values less than 0.05 were included in the model.

Best subset analysis was undertaken with summer (May and August) and winter (February and November) concentrations of $\mathrm{NO}_{3}^{-}, \mathrm{NH}_{4}^{+}, \mathrm{DON}$ and DOC as response variables and the variables representing catchment attributes as explanatory variables. Regional datasets were analysed to assess the single and interactive effect of explanatory variables on surface water $\mathrm{N}$ concentrations and potential $\mathrm{N}$ leaching. Explanatory variables selected for the model include total $\mathrm{N}$ deposition, catchment geomorphology (mean altitude, mean slope, aspect, lake:catchment ratio, extent of bare rock), soil hydrological properties (standard percentage 
The role of catchment characteristics in determining surface water nitrogen in four upland regions in the UK

Table 2(a). Linear regression matrix of $\mathrm{N}$ species (and DOC) and catchment attributes for winter water chemistry

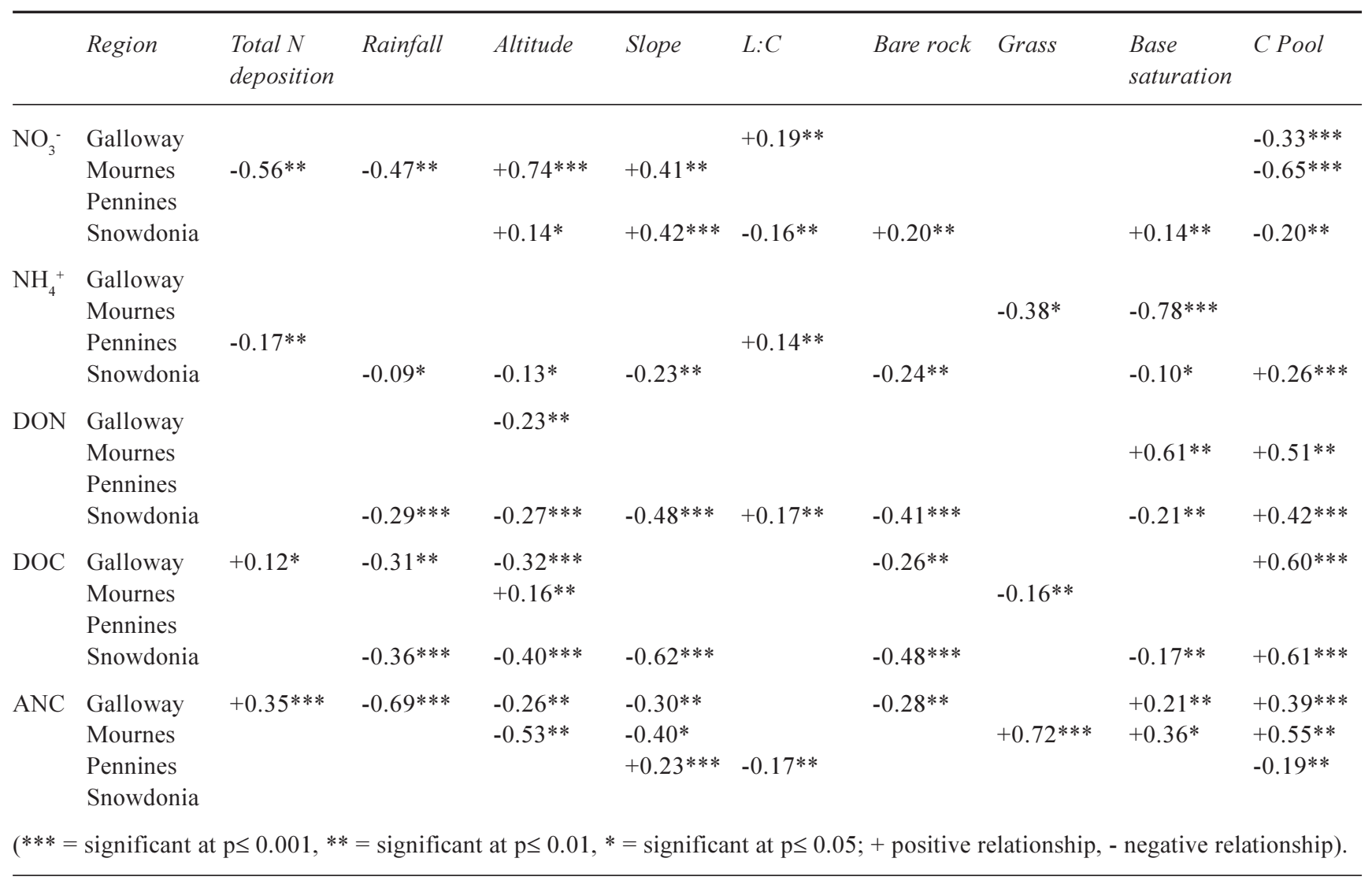

Table 2(b). Linear regression matrix of $\mathrm{N}$ species (and DOC) and catchment attributes for summer water chemistry

\begin{tabular}{|c|c|c|c|c|c|c|c|c|c|c|}
\hline & Region & $\begin{array}{l}\text { Total } N \\
\text { deposition }\end{array}$ & Rainfall & Altitude & Slope & $L: C$ & Bare rock & Grass & $\begin{array}{l}\text { Base } \\
\text { saturation }\end{array}$ & C Pool \\
\hline $\mathrm{NO}_{3}^{-}$ & $\begin{array}{l}\text { Galloway } \\
\text { Mournes } \\
\text { Pennines }\end{array}$ & & $+0.33 * * *$ & & $+0.45 * * *$ & & $+0.18^{*}$ & & & $\begin{array}{l}-0.37 * * \\
-0.30 * *\end{array}$ \\
\hline & Snowdonia & & & $+0.16^{* *}$ & $+0.17 * *$ & & $+0.21 * *$ & & & $-0.24 * *$ \\
\hline $\mathrm{NH}_{4}^{+}$ & $\begin{array}{l}\text { Galloway } \\
\text { Mournes }\end{array}$ & & & $+0.18^{* *}$ & & & & & & \\
\hline & $\begin{array}{l}\text { Pennines } \\
\text { Snowdonia }\end{array}$ & $-0.08^{*}$ & & & $-0.12 * *$ & & $-0.27 * * *$ & & & $\begin{array}{l}+0.12 * * \\
+0.17 * *\end{array}$ \\
\hline DON & $\begin{array}{l}\text { Galloway } \\
\text { Mournes } \\
\text { Pennines }\end{array}$ & $-0.09^{*}$ & $-0.45 * * *$ & $+0.21 * * *$ & $-0.20 * *$ & $-0.16^{*}$ & $-0.32 * *$ & & $+0.36^{* * *}$ & $+0.62 * * *$ \\
\hline & Snowdonia & $-0.16^{* *}$ & $-0.52 * * *$ & $-0.43 * * *$ & $-0.32 * * *$ & & $-0.48 * * *$ & & & $+0.58 * * *$ \\
\hline DOC & $\begin{array}{l}\text { Galloway } \\
\text { Mournes } \\
\text { Pennines }\end{array}$ & & $-0.18^{*}$ & $+0.22 * * *$ & $-0.19^{* *}$ & & $-0.27 * *$ & $-0.07 *$ & & $+0.64 * * *$ \\
\hline & Snowdonia & & $-0.31 * * *$ & $-0.25 * * *$ & $-0.41 * * *$ & & $-0.45 * * *$ & & $-0.10^{*}$ & $+0.45^{* * *}$ \\
\hline ANC & $\begin{array}{l}\text { Galloway } \\
\text { Mournes } \\
\text { Pennines } \\
\text { Snowdonia }\end{array}$ & $+0.15^{*}$ & $-0.57 * * *$ & & $\begin{array}{l}-0.32 * * * \\
-0.32 * \\
+0.19 * *\end{array}$ & $\begin{array}{l}-0.12 * \\
-0.22 * * *\end{array}$ & $-0.42 * * *$ & $\begin{array}{l}+0.89 * * * \\
+0.10 *\end{array}$ & $\begin{array}{l}+0.22 * * \\
+0.81 * * *\end{array}$ & $\begin{array}{l}+0.63 * * * \\
+0.56 * * \\
-0.12 * *\end{array}$ \\
\hline
\end{tabular}


runoff, wetland area) and biophysical properties (soil type, soil base saturation, carbon pool, land-cover type, and geology).

\section{Results and discussion}

\section{REGIONAL COMPARISON OF SURFACE WATER CHEMISTRY AND NITROGEN DEPOSITION}

Surface water chemistry is largely as expected for the acidified regions studied, with most regional surveys exhibiting median $\mathrm{pH}$ values around or below 5.5 and generally low or negative ANC values (Table 3), although there is considerable variability within each region. Analysis of variance (ANOVA) showed large, highly significant $(\mathrm{p} \leq 0.001$ for all surveys) inter-regional differences with regard to acidifying pollutants (Table 3 ); the variability in $\mathrm{xSO}_{4}$ is dramatic, with the South Pennines exhibiting concentrations which are an order of magnitude higher than those in other regions for all surveys.

Significant variability in the concentration and form of surface water nitrogen is observed throughout the four regions. Despite the moderate inter-regional variability in $\mathrm{N}$ deposition and relatively small intra-regional variability, the extent of regional $\mathrm{N}$ leaching differed from site to site. A small number of sites in every region retained most of the $\mathrm{N}$ deposition. However, most sites leached both organic and inorganic $\mathrm{N}$ throughout the year (Table 3). In the Mourne Mountains, inorganic $\mathrm{N}$ is the dominant $\mathrm{N}$ form, representing $62 \%$ of total dissolved N, compared with $48 \%$ in Snowdonia, $46 \%$ in the South Pennines, and 25\% in Galloway. Regional median annual $\mathrm{NO}_{3}{ }^{-}$concentrations are highest in the South

Table 3. Medians and ranges (in brackets) of chemical determinands for all regional surveys.

\begin{tabular}{|c|c|c|c|c|c|}
\hline Determinand & Survey & South Pennines & Snowdonia & Galloway & Mournes \\
\hline \multirow[t]{4}{*}{$\mathrm{pH}$} & Feb & $4.7(4.1-6.5)$ & $5.2(4.4-6.5)$ & $5.1(4.6-6.6)$ & $4.9(4.5-6.1)$ \\
\hline & May & $4.7(4.0-6.7)$ & $5.3(4.6-6.6)$ & $5.3(4.8-6.5)$ & $5.2(4.7-6.1)$ \\
\hline & Aug & $4.6(4.1-6.2)$ & $5.9(4.6-6.7)$ & $5.7(5.2-6.8)$ & $5.3(4.7-6.5)$ \\
\hline & Nov & $4.5(3.9-6.3)$ & $5.5(4.6-6.5)$ & $5.2(4.9-6.3)$ & $4.7(4.3-5.5)$ \\
\hline \multirow{4}{*}{$\begin{array}{l}\text { ANC } \\
\mu \text { eq } 1^{-1}\end{array}$} & Feb & $4(-95-175)$ & $-5(-30-53)$ & $4(-34-83)$ & $1(-30-34)$ \\
\hline & May & $-9(-107-175)$ & $23(-9-132)$ & $3(-36-91)$ & $-34(-76-31)$ \\
\hline & Aug & $14(-75-195)$ & $27(-18-244)$ & $24(-19-151)$ & $13(-31-58)$ \\
\hline & Nov & $-5(-74-178)$ & $23(-20-154)$ & $15(-5-102)$ & $1(-48-48)$ \\
\hline \multirow{4}{*}{$\begin{array}{l}\mathrm{xSO}_{4} \\
\mu \mathrm{eq}^{-1}\end{array}$} & Feb & $129(69-201)$ & $27(12-47)$ & $20(7-24)$ & $31(22-43)$ \\
\hline & May & $122(80-210)$ & $28(13-48)$ & $21(14-30)$ & $38(19-44)$ \\
\hline & Aug & $116(81-214)$ & $33(8-52)$ & $16(7-19)$ & $33(12-41)$ \\
\hline & Nov & $121(65-206)$ & $27(14-43)$ & $24(9-39)$ & $34(27-38)$ \\
\hline \multirow{4}{*}{$\begin{array}{l}\mathrm{NH}_{4}^{+} \\
\mu \mathrm{eq}^{-1}\end{array}$} & Feb & $4.4(1.3-27)$ & $1.6(0.9-4.6)$ & $1.2(0.2-4.6)$ & $2.2(0.8-3.7)$ \\
\hline & May & $2.1(0.9-17)$ & $1.8(0.6-5.9)$ & $0.9(0.4-2.7)$ & $1.2(0.6-2.3)$ \\
\hline & Aug & $2.6(0.2-23)$ & $1.9(1.0-4.0)$ & $0.9(0.2-2.3)$ & $2.8(1.2-11)$ \\
\hline & Nov & $3.2(1.6-9.5)$ & $1.7(0.9-3.8)$ & $1.3(0.2-3.3)$ & $2.4(0.2-5.9)$ \\
\hline \multirow{4}{*}{$\begin{array}{l}\mathrm{NO}_{3}^{-} \\
\mu \text { eq } 1^{-1}\end{array}$} & Feb & $26(13-45)$ & $10(2.9-28)$ & $10(0.2-13)$ & $25(12-46)$ \\
\hline & May & $26(7-41)$ & $8(0.7-27)$ & $10(0.2-22)$ & $26(0.2-42)$ \\
\hline & Aug & $20(0.7-36)$ & $1.3(0.7-26)$ & $0.2(0.2-8.8)$ & $9(0.2-23)$ \\
\hline & Nov & $21(10-38)$ & $10(0.7-26)$ & $3.7(1.1-8.9)$ & $20(6-27)$ \\
\hline \multirow{4}{*}{$\begin{array}{l}\text { DON } \\
\mu \mathrm{mol} \mathrm{l}^{-1}\end{array}$} & Feb & $21.4(0-37.1)$ & $9.3(2.1-21.4)$ & $12.1(0.7-16.4)$ & $7.9(0-15.7)$ \\
\hline & May & $25.7(0-56.4)$ & $10.7(0.7-35)$ & $12.5(7.9-19.3)$ & $7.9(1.4-22.1)$ \\
\hline & Aug & $55.4(25.7-110)$ & $17.9(7.1-42.9)$ & $25.7(7.1-52.9)$ & $25.7(10-40)$ \\
\hline & Nov & $32.5(0-50)$ & $7.9(2.9-22.9)$ & $17.9(10-30.7)$ & $10(8.6-21.4)$ \\
\hline \multirow{4}{*}{$\begin{array}{l}\text { DOC } \\
\mu \mathrm{mol} \mathrm{1} 1^{-1}\end{array}$} & Feb & $646(233-1083)$ & $167(25-425)$ & $346(218-532)$ & $319(238-597)$ \\
\hline & May & $517(142-858)$ & $250(42-642)$ & $321(176-778)$ & $294(214-682)$ \\
\hline & Aug & $829(142-1833)$ & $300(108-667)$ & $672(228-2371)$ & $730(328-1562)$ \\
\hline & Nov & $921(150-1358)$ & $208(50-575)$ & $408(196-692)$ & $368(263-572)$ \\
\hline
\end{tabular}


Pennines $\left(23 \mu \mathrm{eq}^{-1}\right)$ and the Mourne Mountains $\left(20 \mu \mathrm{eq} \mathrm{l}^{-1}\right)$ and lower in Galloway and Snowdonia (6 $\mu \mathrm{eq} \mathrm{l}^{-1}$ and $7 \mu \mathrm{eq} \mathrm{I}^{-1}$ respectively). In terms of proportional contribution to acidity (defined as $\mathrm{NO}_{3} / \mathrm{NO}_{3}+\mathrm{xSO}_{4}$ ), the Mourne Mountains are the most highly affected by $\mathrm{NO}_{3}$ as this region has much lower $\mathrm{xSO}_{4}$ concentrations than the South Pennines (Table 3).

DON shows strong regional patterns, which mirror those of DOC closely. The linear regression of DON against DOC for all sites and seasons is highly significant $\left(\mathrm{R}^{2}=0.76\right.$, $\mathrm{p} \leq 0.001)$. This finding is comparable to a study of stream chemistry in Scotland $\left(\mathrm{R}^{2}=0.77, \mathrm{p} \leq 0.001\right)$ (Chapman et $a l ., 2001)$. DON is the dominant $\mathrm{N}$ fraction in Galloway (75\%), Snowdonia (52\%) and the South Pennines (54\%), with relatively high (but variable) concentrations in the surface waters of the South Pennines (annual median $33.7 \mu \mathrm{mol} \mathrm{l}^{-1}$ ) and lower levels in all other regions (annual medians 17.1, 12.9 and $11.5 \mu \mathrm{mol} \mathrm{l}^{-1}$ in Galloway, the Mournes and Snowdonia respectively). While DON may appear to be a 'benign' removal mechanism for catchment $\mathrm{N}$, if it is subsequently mineralised downstream of sampling sites then this has implications for surface water acidity.

\section{SEASONAL VARIATIONS IN SURFACE WATER NITROGEN CONCENTRATIONS}

A clear seasonal difference in surface water $\mathrm{N}$ concentrations between summer and winter is observed in all regions, with inorganic $\mathrm{N}$ concentrations highest in winter, and DON and DOC concentrations highest in summer. This seasonal signal is most marked in Galloway, where summer $\mathrm{NO}_{3}$ concentrations fall below detection limits for most sites, and least marked in the South Pennines, which show year round high $\mathrm{NO}_{3}$ leaching (median values $>20 \mu \mathrm{eq} 1^{-1}$ for all surveys). For $\mathrm{NH}_{4}$, seasonal variation is less obvious due to the relatively low concentrations of this ion in surface waters, although several sites in the South Pennines have very high summer $\mathrm{NH}_{4}$ concentrations. For DON, high summer concentrations are observed at the majority of sites, with the greatest seasonal variability being apparent in the South Pennines and at some higher DON sites in Snowdonia.

\section{RELATIONSHIP OF NITROGEN DEPOSITION TO SOIL AND SURFACE WATER NITROGEN CONCENTRATIONS}

Many studies have linked $\mathrm{N}$ deposition inputs to $\mathrm{N}$ leaching across a range of input fluxes (Allott et al., 1995), and deposition thresholds have been proposed for both the onset of $\mathrm{N}$ leaching and for elevated leaching (Dise and Wright, 1995; Gundersen et al., 1998). A clear positive relationship between total $\mathrm{N}$ inputs and outputs across the survey regions was observed. The South Pennines have the highest input and output $\mathrm{N}$ fluxes, followed by the Mourne Mountains and Galloway, but no clear trend is evident for the Snowdonia region. The majority of $\mathrm{N}$ inputs $(60 \%)$ are retained within catchments.

With regard to the relationship between $\mathrm{N}$ deposition and organic $\mathrm{N}$, there has been much speculation about the role of $\mathrm{N}$ deposition in determining soil pools of organic $\mathrm{N}$ and consequently $\mathrm{N}$ leaching to surface waters. It appears that, for the catchments studied here, the ratio of surface water DOC to DON is a negative function of $\mathrm{N}$ deposition (Fig. 2). Although the relationship is weak and does not hold for the February or November surveys when levels of DOC and DON are low (plots not shown), it does demonstrate that regions of high $\mathrm{N}$ deposition (such as the South
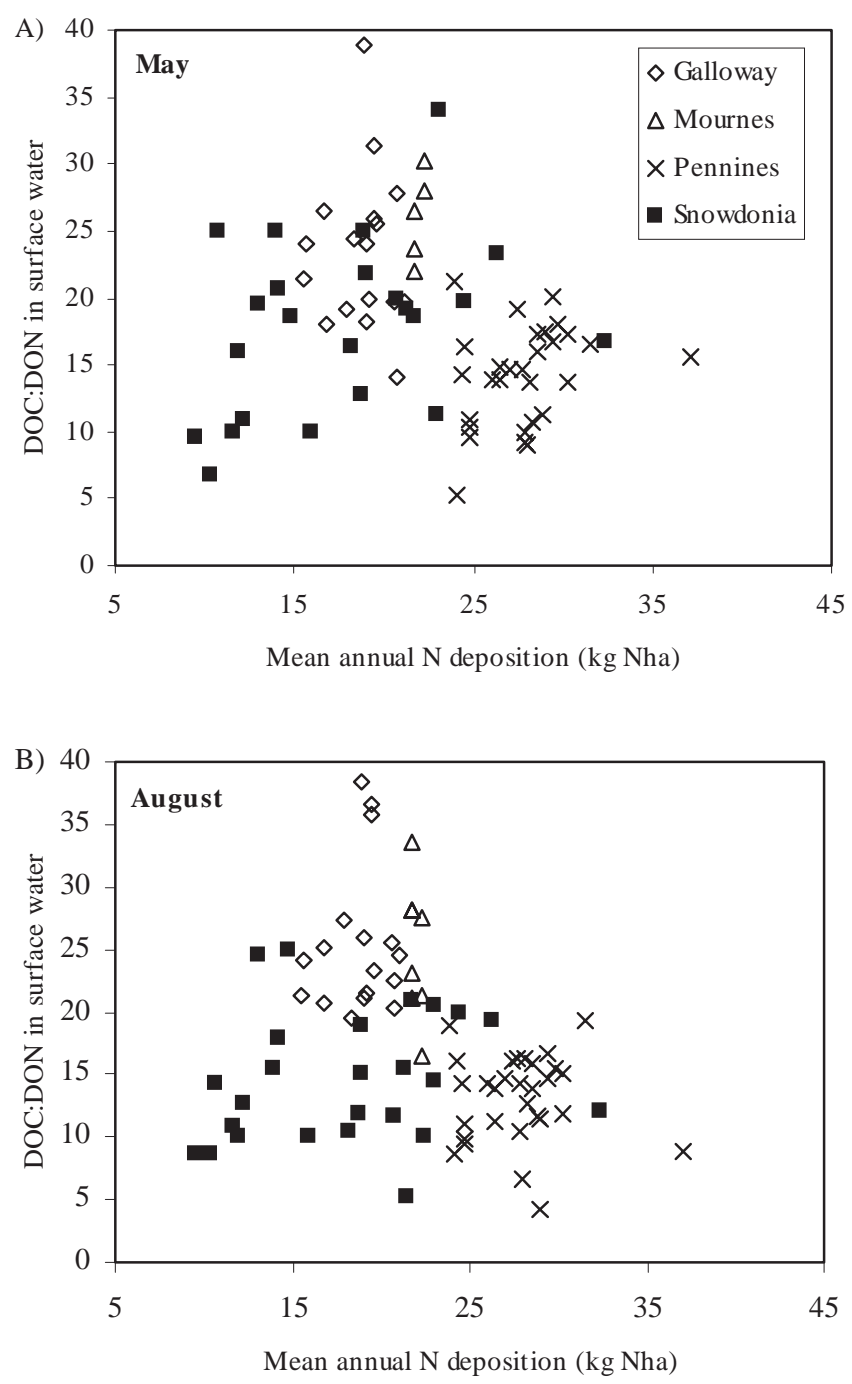

Fig. 2. DOC/DON ratios in surface waters vs. $N$ deposition. 
Pennines) tend to exhibit lower DOC/DON ratios than those receiving lower deposition inputs (e.g. Galloway). This implies that in regions of high $\mathrm{N}$ deposition, the assimilation of inorganic $\mathrm{N}$ into organic $\mathrm{N}$ may reduce the $\mathrm{C}: \mathrm{N}$ of catchment soils with deleterious consequences for leaching of inorganic $\mathrm{N}$.

However, the concentration of $\mathrm{N}$ species in surface waters is dependent on a number of complex geomorphic characteristics and biogeochemical processes. To disentangle these complex attributes and processes, winter and summer $\mathrm{N}$ data were compared. It is hypothesised that in the winter months, geomorphic (abiotic) attributes have a greater influence on surface water $\mathrm{N}$ concentrations than in the summer, when catchment characteristics associated with biological uptake and transformation are more important.

\section{GEOMORPHIC INFLUENCES ON WINTER SURFACE WATER NITROGEN AND DISSOLVED ORGANIC CARBON CONCENTRATIONS}

\section{Linear regression}

Statistical relationships between regional winter concentrations of $\mathrm{N}$ and catchment characteristics were examined initially by linear regression analysis. Clear geomorphic influences on surface water $\mathrm{N}$ are observed in the Galloway, Snowdonia and Mourne regions (Fig. 3). Snowdonia is the most mountainous region in the study, with high altitude sites (median height of $\sim 500 \mathrm{~m}$ ) characterised by steep slopes (median slope $\sim 14$ degrees) and large areas of bare rock (median area 30\%). Linear regression analysis indicates that surface water $\mathrm{NO}_{3}^{-}$ concentrations in Snowdonia are positively related to the site geomorphology (mean slope $\mathrm{r}^{2}=+0.42 * * *$ and altitude $\left.\mathrm{r}^{2}=+0.14^{*}\right)$ and area of bare rock $\left(\mathrm{r}^{2}=+0.20^{* *}\right.$; Table $2 \mathrm{a}$, Fig. 3,a,b,c). Catchments with large expanses of rock are associated with high $\mathrm{NO}_{3}^{-}$concentrations which indicate that net $\mathrm{N}$ immobilisation is limited by sparse soil and vegetation cover. Despite the limited number of sites in the Mourne region, a strong geomorphic influence was also observed for winter $\mathrm{NO}_{3}^{-}$concentrations. In this region, $\mathrm{NO}_{3}{ }^{-}$concentrations are significantly higher at sites dominated by steeper slopes $\left(\mathrm{r}^{2}=+0.41^{* *}\right)$ at high altitude $\left(\mathrm{r}^{2}=+0.74^{* * *}\right.$, Table $2 \mathrm{a}$ ), as found in other studies (Kamenik et al., 2001; Kernan and Allot, 1999; Kopácek et al., 2000). Whilst similar relationships are observed in the Galloway region, no geomorphic influences on surface water $\mathrm{N}$ are apparent in the South Pennine region. Overall, $\mathrm{NO}_{3}^{-}$is positively related with these catchment attributes whilst $\mathrm{NH}_{4}^{+}$, DON and DOC are negatively related (Table 2a).

Nitrogen inputs can be modified by catchment

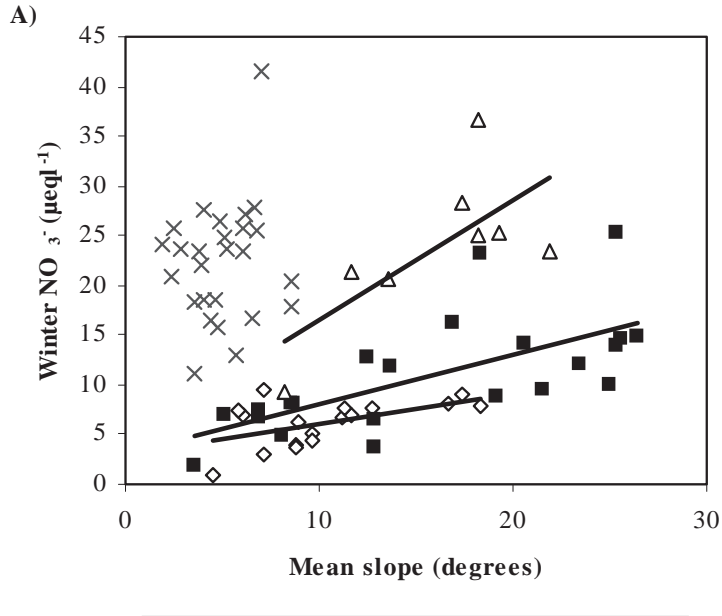

$\diamond$ Galloway $\square$ Snowdonia $\Delta$ Mournes $\times$ Pennines

B)



$\diamond$ Galloway $\square$ Snowdonia $\Delta$ Mournes $\times$ Pennines

C)

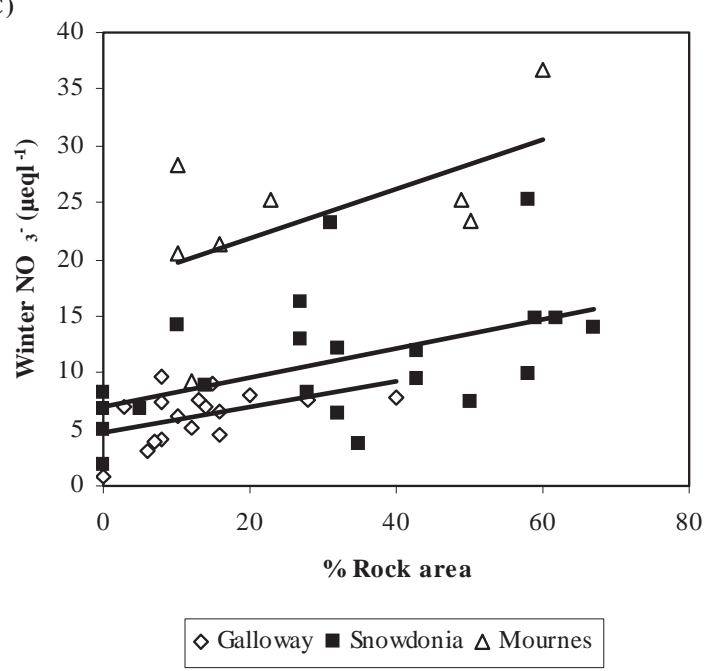

Fig. 3. Regional relationships between the catchment attributes, (a) slope, (b) attitude, and (c) rock area with winter $\mathrm{NO}_{3}^{-}$ concentrations. 
geomorphology (in terms of soil development) by influencing the hydrological pathways through, for example, rapidly draining coarse grained mountain soils, to imperfectly drained peaty gleys and peats which may form deposits several metres thick. Rapid water movement occurs during events of heavy rainfall and snowmelt, thus reducing the contact time between soil and water. At high altitude sites dominated by rock in the Snowdonia and Mournes regions, the role of soil and vegetation in $\mathrm{N}$ retention processes is likely to be superseded by hydrological factors; a process identified elsewhere (Kaste et al., 1997; Kopácek et al., 2000). Conversely, in the Galloway region, where soils are relatively well developed on gentle slopes, longer soil water residence times (median SPR 55\%, Table 1) with $\mathrm{N}$-enriched soil water may lead to larger pools of soil $\mathrm{N}$ and enhanced nitrification in warmer months. Other variables that influence catchment hydrology such as the estimated wetland area had little effect on either surface water $\mathrm{N}$ or DOC, although some $\mathrm{N}$ species and DOC were weakly related to rainfall in some regions (Table 2a).

\section{BIOGEOCHEMICAL INFLUENCES ON SUMMER SURFACE WATER NITROGEN AND DISSOLVED ORGANIC CARBON CONCENTRATIONS}

\section{Linear regression}

Linear regression analysis of data from all 80 sites in this study shows a strong positive relationship between peat coverage and DON $\left(\mathrm{r}^{2}=+0.44^{* * *}\right.$; Fig. $\left.4 \mathrm{a}\right)$ and peat coverage and DOC $\left(\mathrm{r}^{2}=+0.36^{* * *}\right)$. This result confirms that higher DON and DOC concentrations occur in surface waters draining organic rich catchments; the highest DON and DOC concentrations are apparent in the South Pennines, a region dominated by peat and the lowest concentrations are observed in Snowdonia where mineral soils and bare rock dominate many of the catchments. However, similar analysis of summer $\mathrm{NO}_{3}^{-}$concentrations against the percentage coverage of peat was not statistically significant at the $95 \%$ confidence level.

Several studies have attempted to link the soil C pool (an indicator of the organic status of soils within a catchment) and surface soil C:N ratio with soil water and surface water $\mathrm{NO}_{3}{ }^{-}$concentrations (Evans et al., 2005; Gundersen et al., 1998; Helliwell et al., 2001; Kristensen et al., 2004; Lovett et al., 2002), but the majority of these studies focused on forested ecosystems. Estimation of $\mathrm{C}$ pools at the catchment scale is hard to quantify, but surface water DOC is an effective proxy and previous work has established a linear relationship between catchment C pool and DOC export (Hope et al., 1997). In this study of moorland catchments, enhanced confidence in the $\mathrm{C}$ pool methodology is demonstrated by a strong inter-regional relationship between catchment $\mathrm{C}$ pool and summer surface water DOC concentrations in the Galloway and Snowdonia regions $\left(r^{2}=+0.64 * * *\right.$ and $r^{2}=+0.45^{* * *}$ respectively, Fig. $\left.4 \mathrm{~b}\right)$.

It is hypothesised that surface water $\mathrm{NO}_{3}^{-} / \mathrm{DOC}$ relationships are equivalent to $\mathrm{NO}_{3}^{-} / \mathrm{C}$ pool relationships within regions of approximately uniform deposition (Evans et al., 2005). A statistically significant inverse relationship is apparent between catchment-weighted soil $\mathrm{C}$ pools and summer surface water $\mathrm{NO}_{3}{ }^{-}$in the Galloway, Mournes and Snowdonia regions $\left(\mathrm{r}^{2}=-0.37^{* *}, \mathrm{r}^{2}=-0.30^{* *}\right.$ and $\mathrm{r}^{2}=-0.24 * *$ respectively Fig. $4 \mathrm{c}$ ), but this relationship was not evident in the South Pennine region. Gundersen et al. (1998) identified a simple index of catchment $\mathrm{N}$ status in the form of soil $\mathrm{C}: \mathrm{N}$ ratios, and related these to $\mathrm{N}$ leaching by examining the forest floor of a number of plots across Europe. The implication of this study was that where soil $\mathrm{C}: \mathrm{N}$ ratios are less than $25, \mathrm{~N}$ leaching is likely, but no relationship between mean catchment soil $\mathrm{C}: \mathrm{N}$ ratios and total inorganic $\mathrm{N}$ export from these catchments is evident from the regional data (Fig. 4d). This is to be expected for a number of reasons: the relatively few samples taken in each catchment, the considerable within-catchment variability with regard to $\mathrm{C}: \mathrm{N}$ ratios, the difficulty of identifying and sampling hydrologically more important soils which may play a greater role in determining surface water chemistry than catchment soils as a whole (Billet and Cresser, 1992; Mulder et al., 1991; Stoddard, 1994); the variability of soil pathways with hydrological conditions (Guisti and Neal, 1993); and the fact that several soil horizons (litter, fermentation, humus and organic) were sampled and which may be highly variable with regard to organic carbon and nitrogen concentrations.

A preliminary investigation of surface 'water' temperature as an explanatory variable of nitrogen concentration proved inconclusive; it is possible, therefore, that in-lake mechanisms such as denitrification, which is a temperaturedependent process, are not controlling $\mathrm{N}$ concentrations in this study. However, in a study of 13 catchments in northern Scotland, Clark et al. (2004) found mean monthly 'air' temperature emerged as a significant factor in explaining the variability in surface water $\mathrm{NO}_{3}^{-}$concentrations, yielding an $\mathrm{r}^{2}=0.82$. It is, therefore, assumed that a temperature mediated change in activity of $\mathrm{N}$ cycling bacteria may occur around $5^{\circ} \mathrm{C}$, or that plant uptake of $\mathrm{N}$ may be significantly reduced below $5^{\circ} \mathrm{C}$. In addition, soil temperature, although not measured here, was found to be dependent on aspect (Watson et al., 1994). In the study reported here, total dissolved $\mathrm{N}$ concentrations in summer were correlated positively with sites with colder predominantly north, northeast and north-west facing slopes in the Mourne Mountains. 
A)

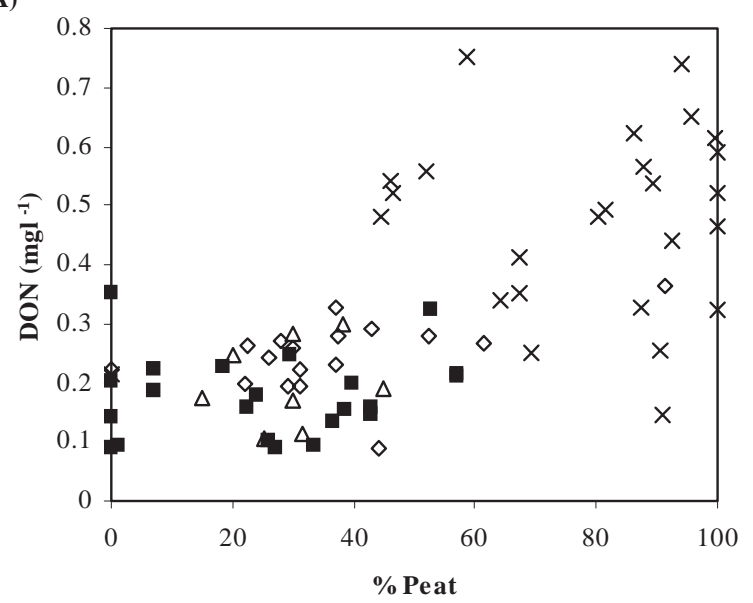

$\diamond$ Galloway $\square$ Snowdonia $\Delta$ Mournes $\times$ South Pennines

C)

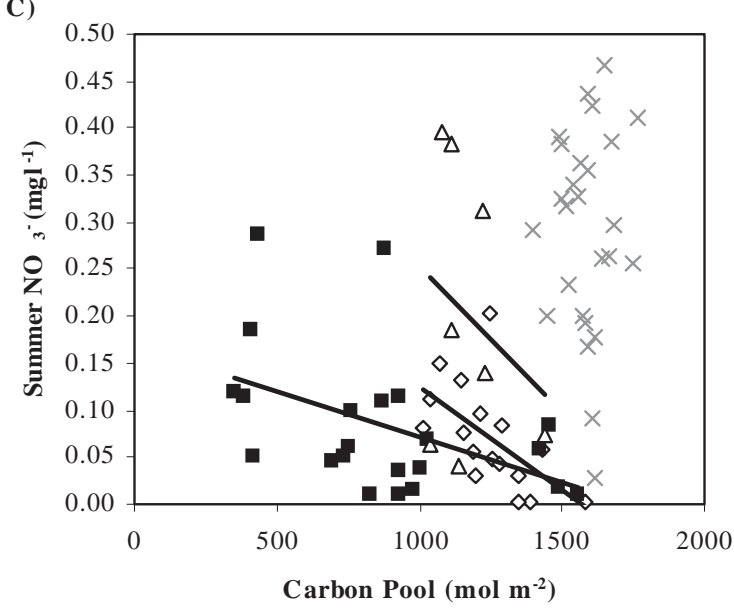

$\diamond$ Galloway $\square$ Snowdonia $\Delta$ Mournes $\times$ South Pennines

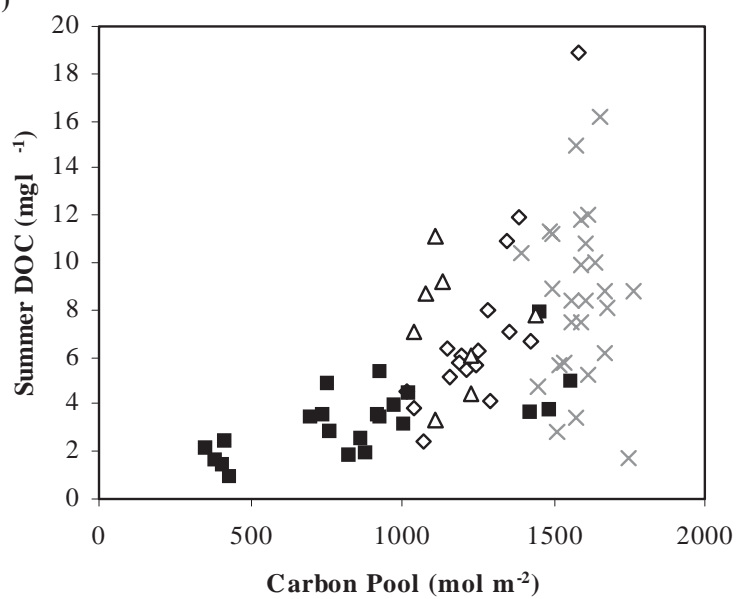

$\diamond$ Galloway $\square$ Snowdonia $\Delta$ Mournes $\times$ South Pennines

D)

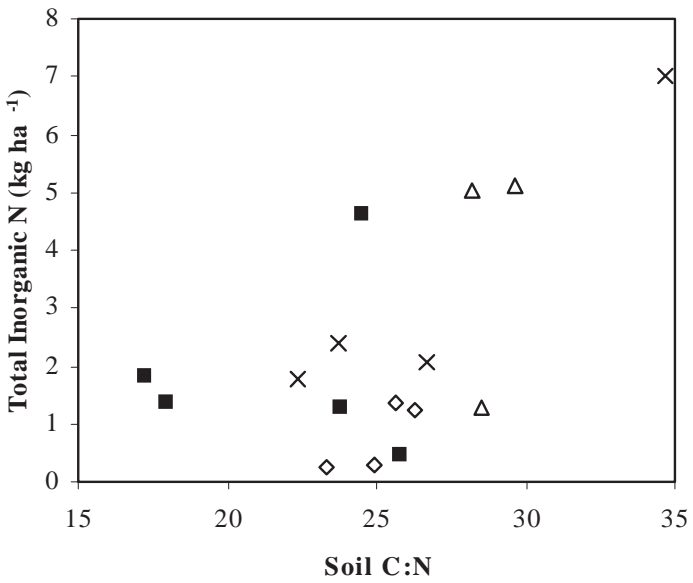

$\Delta$ Galloway $\square$ Snowdonia $\Delta$ Mournes $\times$ South Pennines

Fig. 4. Regional relationships between (a) \% peat and summer surface water DON, (b) soil C pool and summer surface water DOC, (c) soil C pool and summer $\mathrm{NO}_{3}^{-}$leaching, and (d) soil $\mathrm{C}: \mathrm{N}$ ratio and total inorganic $\mathrm{N}$ flux from the summer survey.

Assuming that soil temperatures are lower at these north facing sites, it is likely that $\mathrm{N}$ immobilisation will be reduced.

Elevated summer $\mathrm{NO}_{3}{ }^{-}$concentrations were also apparent at high altitude sites with sparse soil and vegetation cover in the Snowdonia, Mourne and Galloway regions (Table $2 b)$. These sites have a low uptake capacity and slightly shorter growing season and, therefore, lack the $\mathrm{N}$ retention capabilities of moorland sites at lower altitudes with welldeveloped soils and established vegetation. In these circumstances, these soils' ability to retain external inputs of $\mathrm{N}$ is dependent on the existing $\mathrm{N}$ supply in relation to chemical $\mathrm{N}$ demand (immobilisation of soil organic matter) and the combined plant and microbial $\mathrm{N}$ uptake capacity.

In summer, $\mathrm{NH}_{4}^{+}$concentrations observed in most regions are below the detection limit resulting in a weak relationship with the catchment characteristics identified in Table $2 \mathrm{~b}$. Ammonium may be nitrified or assimilated preferentially by biological communities (Curtis et al., 1998), and these processes may explain the high net retention $(>90 \%$ for most catchments) observed in many previous studies (Dillon and Molot, 1990; Dise and Wright, 1995). A few sites in each region with high surface water $\mathrm{NH}_{4}^{+}$concentrations are typically at higher elevation. Biological activity at these sites is likely to be low and, where soils are waterlogged, oxidation may be inhibited. Leached $\mathrm{NH}_{4}^{+}$will be taken up eventually by aquatic vegetation or oxidised to $\mathrm{NO}_{3}^{-}$ downstream of sampling sites, causing further acidification (Evans et al., 2000). 
The role of catchment characteristics in determining surface water nitrogen in four upland regions in the UK




The weathering rate and base status of the soil had a negligible effect on summer concentrations of $\mathrm{N}$ and DOC. However, stronger relationships are identified between winter chemistries particularly in the Mournes where BS\% is negatively related to $\mathrm{NH}_{4}^{+}\left(\mathrm{r}^{2}=-0.78^{* * *}\right)$ and positively related to DON $\left(\mathrm{r}^{2}=0.61^{* *}\right)$.

Stepwise multiple regression (best subset analysis) on winter and summer datasets

Inter-relationships between catchment attributes generated by the best subset models generally explain more variation in $\mathrm{N}$ concentrations than simple linear regression analyses. This illustrates the highly integrated nature of catchment systems and the wide range of environmental factors that determine the $\mathrm{N}$ composition and concentration of surface waters. The same explanatory variables are used in both winter and summer models to explore inter-relationships between a number of catchment characteristics and surface water $\mathrm{N}$ and DOC concentrations. When interactions between catchment attributes are assessed in stepwise multiple regression analyses, different regional catchment characteristics to those identified from linear regression models are considered to be important descriptors of $\mathrm{N}$ leaching.

The models that explain the greatest variance in this study were derived for winter $\mathrm{NO}_{3}^{-}$(variance explained 99\%, $\left.\mathrm{p} \leq 0.005^{* *}\right), \mathrm{NH}_{4}^{+}\left(78 \%, \mathrm{p} \leq 0.002^{* *}\right)$, and DON $(75 \%$, $\mathrm{p} \leq 0.003^{* *}$ ) concentrations in the Mournes (Table 4a). Given that this region comprises only eight sites, these results should be interpreted with some caution. Regression models for the South Pennine region are generally poor, adding further confirmation that the main drivers of $\mathrm{N}$ leaching are not represented adequately for this region. An alternative explanation for the poor $\mathrm{N}$ models in the South Pennines might be that the plant and soil microbial communities are significantly stressed as a consequence of high historical sulphur and nitrogen deposition, resulting in a lower potential to assimilate the deposited $\mathrm{N}$. Catchment weighted C pool is an important descriptor for winter $\mathrm{NO}_{3}{ }^{-}$ concentration in the Galloway (variance explained 33\%, $\mathrm{p} \leq 0.001^{* * *}$ ) and the Mourne (variance explained 65\%, $\mathrm{p}=0.000^{* * *}$ ) regions. Less variability was accounted for in the model for $\mathrm{NH}_{4}^{+}$in Snowdonia (26\%, $\left.\mathrm{p} \leq 0.001^{* * *}\right)$; and DON in Galloway $\left(8 \%, \mathrm{p} \leq 0.008^{* *}\right)$ and Snowdonia ( $42 \%$, $\mathrm{p}=0.000^{* * *}$, Table $\left.4 \mathrm{a}\right)$. This result suggests that the soil C pool is, with other terms highlighted in the models, a key attribute with the potential to influence the release of $\mathrm{N}$ from the soil into surface waters in both winter and summer. However, the importance of the $\mathrm{C}$ pool in the winter model is simply a function of altitude and slope because biological activity is negligible in the winter months.
Summer models generally explain less variation in surface water $\mathrm{N}$ than the winter models, except for DON in the Galloway and the Mourne regions (Table 4b). The best model to account for the variability in summer surface water $\mathrm{NO}_{3}{ }^{-}$concentrations is derived for the Galloway region where $65 \%$ of the variance is explained by slope $\left(\mathrm{P}=0.000^{* * *}\right)$ and lake:catchment ratio $\left(\mathrm{P} \leq 0.009^{* *}\right)$. In the Mourne region, $53 \%$ of the variation is attributable to the catchment aspect $((\mathrm{P} \leq 0.035)$ and $\mathrm{BS} \%(\mathrm{P} \leq 0.043 *)$, and $21 \%$ of the variance in Snowdonia is explained by the area of rock $\left(\mathrm{P} \leq 0.019^{*}\right)$. The model for Snowdonia is comparable with results from a similar study of 76 acid sensitive lakes in the same region (Kernan et al., 1999) where percentage bare ground was the principal explanatory variable identified in the analysis of summer $\mathrm{NO}_{3}{ }^{-}$data. Unlike the study conducted by Kernan et al (1999), where no catchment variables explained the variation in $\mathrm{NH}_{4}^{+}$concentrations in the Snowdonia region, in this study a complex model for summer $\mathrm{NH}_{4}^{+}$involving the following key variables: area of rock (27\%), altitude (13\%), SPR (6\%) and grass $(9 \%)$ has been produced. Different models were produced for DON that explained $71 \%$ (Galloway), 73\% (Snowdonia), and $22 \%$ (South Pennines) of the variability in DON concentrations (Table $4 b$ ).

The catchment attributes selected for these analyses do not represent adequately the main soil processes and catchment controls that are responsible for the release of inorganic $\mathrm{N}$ to surface waters in the South Pennines.

\section{Conclusion}

Nitrogen deposition can cause ecological damage in acid sensitive soils and waters. The geophysical configurations of upland sites investigated in this study influence the distribution and coverage of vegetation and soil types; they also determine the organic content of soils which have been identified as key attributes in explaining $\mathrm{N}$ leaching at a regional scale (Fig. 5). Linear regression models indicate that (a) catchment attributes influence both the concentration and composition of $\mathrm{N}$ in surface waters, and (b) surface water $\mathrm{N}$ enrichment is greatest in high altitude catchments with steep slopes, thin mineral soils and low levels of soil carbon. When these catchment factors are taken into account, regions with higher $\mathrm{N}$ deposition are generally at greater risk of increased $\mathrm{N}$ leaching (Fig. 5).

From linear and 'best subset' (multiple regression) analysis, different catchment characteristics were identified as important descriptors of $\mathrm{N}$ leaching for each region. This implies that the inter-regional heterogeneity in catchment attributes influences both the concentration and composition of $\mathrm{N}$ in surface water. Different regional models $\mathrm{NO}_{3}{ }^{-}, \mathrm{NH}_{4}^{+}$, 


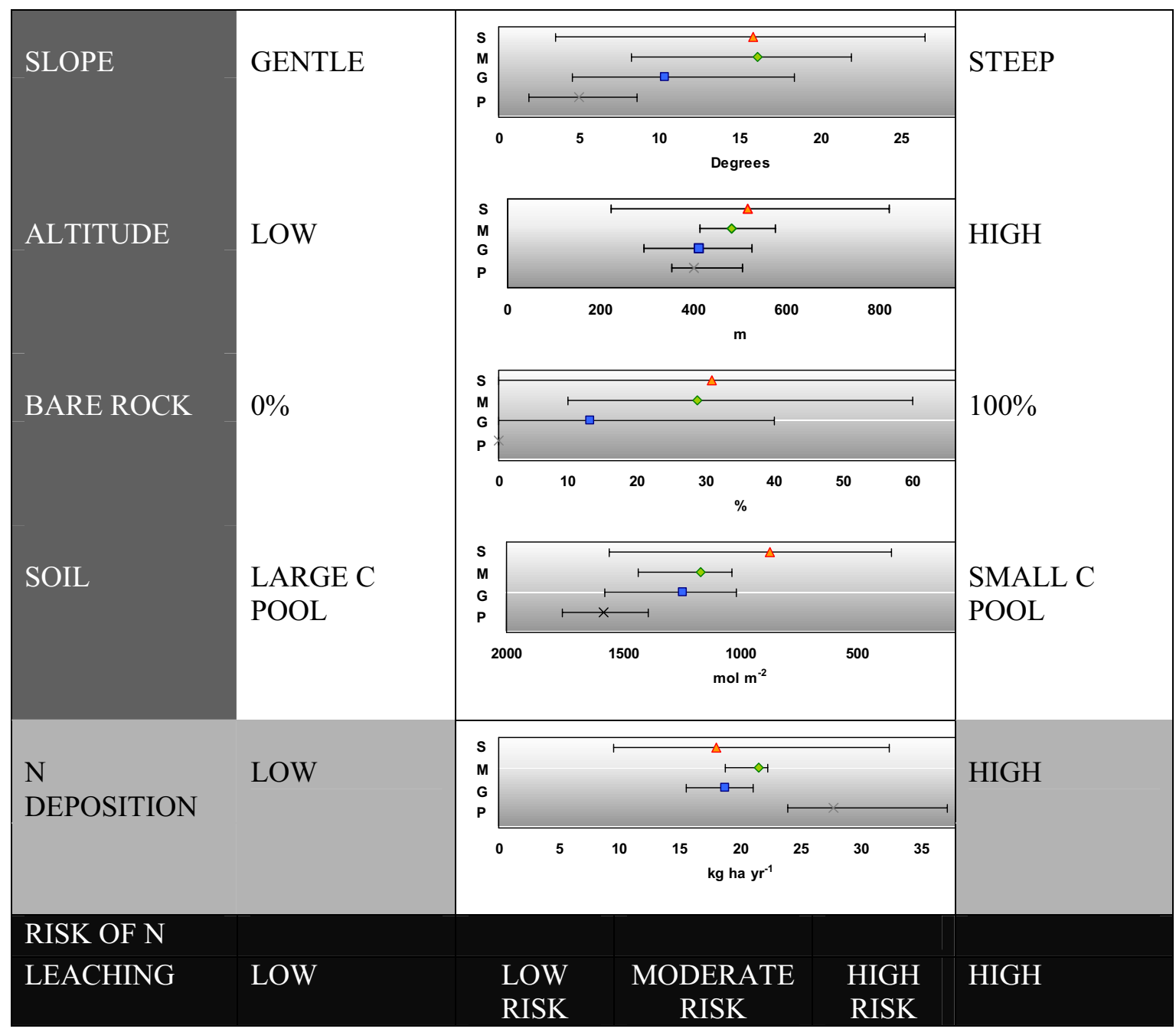

Fig. 5. Risk of winter $N$ leaching in response to geomorphic catchment attributes and N deposition (Snowdonia (S), Mournes (M), Galloway (G), Pennines (P)).

DON and DOC are derived for data collected in winter (February/November) and in summer (May/August) surveys. During the winter, biological uptake and transformation of $\mathrm{N}$ is greatly reduced. With biological influences factored out of the winter analysis, there was a strong positive relationship between geomorphic characteristics (slope, altitude and extent of bare rock) and winter $\mathrm{NO}_{3}^{-}$concentrations in Snowdonia, Galloway and the Mournes. These variables were important in determining both the size of vegetation and soil sinks for $\mathrm{N}$ as well as the hydrological pathways and residence times which control the transport of $\mathrm{N}$ through the catchments. Highly significant relationships between summer surface water $\mathrm{NO}_{3}{ }^{-}$and soil C pool were observed in Snowdonia, Galloway and the Mournes. Nitrate concentrations in waters draining catchments dominated by peaty soils (large $\mathrm{C}$ pool) were considerably lower than those in catchments dominated by mineral soils (small $\mathrm{C}$ pool). The poor level of explanation for $\mathrm{N}$ concentration in the South Pennine region implies that environmental factors other than those included in this study must be identified to improve the $\mathrm{N}$ models. An apparent breakdown of soil controls on nitrate leaching in the South Pennine region leads to consistently high $\mathrm{N}$ concentrations at all sites and throughout the year.

The spatial variation in $\mathrm{N}$ leaching from moorland ecosystems investigated in this study is largely a predictable function of geomorphic characteristics that influence both the soil and vegetation $\mathrm{N}$ sink and the total catchment carbon pool. These catchment attributes are currently being considered in the most recent application of the dynamic 
acidification model, MAGIC, in an attempt to improve the representation of the dynamics of $\mathrm{N}$ retention and loss in the four study regions.

\section{Acknowledgements}

This work was supported by the Natural Research Council Global Nitrogen Enrichment programme (NER/T/S/2000/ 00222, NER/T/S/2000/00935 and NER/T/S/2000/00934), Department of the Environment, Food and Rural Affairs (DEFRA) Terrestrial Umbrella (Effects of eutrophication and acidification on terrestrial ecosystems (CPEA 18)) and the Scottish Executive Environment and Rural Affairs Department (SEERAD). The authors are indebted to colleagues for their involvement in the regional soil and water surveys including Allan Lilly, Beate Gannon, Vicky Shackle, Roger Wyatt, Marie Donald, Monika Jürgens, Ann Dixon, Marc Stutter and Richard Hewison. The analytical chemistry departments at the Macaulay Institute and Centre of Ecology and Hydrology (Wallingford) are acknowledged, particularly Sheila Gibbs. Thanks are also due to Ian Enlanders from the Environment and Heritage Service (Department of the Environment Northern Ireland) for providing useful background information to the Mourne region and Ronnie Bailie from Water Services (Department of Regional Development) for allowing access to the sample sites in the Mourne mountains.

\section{References}

Allott, T.E.H., Curtis, C.J., Hall, J., Harriman, R. and Battarbee, R.W., 1995. The impact of nitrogen deposition on upland surface waters in Great Britain: A regional assessment of nitrate leaching. Water Air Soil Pollut., 85, 297-302.

Billett, M.F. and Cresser, M.S., 1992. Predicting stream-water quality using catchment characteristics and soil chemical characteristics. Environ. Pollut., 77, 263-268.

Boorman, D.B., Hollis, J.M. and Lilly, A., 1995. Hydrology of soil types: a hydrologically based classification of the soils of the United Kingdom. Institute of Hydrology, UK. Report no. 126.

Chapman, P.J. and Edwards, A.C., 1999. The impact of atmospheric nitrogen deposition on the behaviour of nitrogen in surface waters. In: The impact of nitrogen deposition on natural and semi-natural ecosystems, S.J. Langan (Ed.), Environmental Pollution, Vol 3, Kluwer Academic Publishers, Dordrecht, The Netherlands. 153-212.

Chapman, P.J., Edwards, A.C. and Cresser, M.S., 2001. The nitrogen composition of streams in upland Scotland: some regional and seasonal differences. Sci. Total Envir., 265, 6583.

Clark, M.J., Cresser, M.S., Smart, R., Chapman, P.J. and Edwards, A.C., 2004. The influence of catchment characteristics on the seasonality of carbon and nitrogen species concentrations in upland rivers of Northern Scotland. Biogeochem., 68, 1-19.
Curtis, C.J., Allott, T.E.H., Reynolds, B. and Harriman, R., 1998. The prediction of nitrate leaching with the First-order Acidity Balance (FAB) model for upland catchments in Great Britain. Water Air Soil Pollut., 105, 205-215.

Curtis, C.J., Evans, C.D., Helliwell, R.C. and Monteith, D.T., 2005. Nitrate leaching as a confounding factor in chemical recovery from acidification in UK upland waters. Environ. Pollut., 137, 73-82.

Davies, J.J.L., Jenkins, A., Monteith, D.T., Evans, C.D. and Cooper D.M., 2005. Trends in surface water chemistry of acidified UK Freshwaters, 1988-2002. Environ. Pollut., 137, 27-39.

Dillon, P.J. and Molot, L.A., 1990. The role of ammonium and nitrate retention in the acidification of lakes and forested catchments. Biogeochem., 11, 23-43.

Dise, N.B. and Wright, R.F., 1995. Nitrogen leaching from European forests in relation to nitrogen deposition. Forest Ecol. Manage., 71, 153-161.

Evans, C.D. and Jenkins, A., 2000. Surface water acidification in the South Pennines II. Temporal trends. Environ. Pollut., 109, 21-34.

Evans, C.D., Jenkins, A. and Wright, R.F., 2000. Surface water acidification in the South Pennines I. Current status and spatial variability. Environ. Pollut., 109, 11-20.

Evans, C.D., Reynolds, B., Jenkins, A., Helliwell, R.C., Curtis, C.J., Goodale, C.L., Ferrier, R.C., Emmett, B.E., Pilkington, M.G., Caporn, S.J.M., Carroll, J.A., Norris, D., Davies, J. and Coull, M.C., 2005. Evidence that soil carbon pool determines susceptibility of semi-natural ecosystems to elevated nitrogen leaching. Ecosystems, 9, 453-462.

Fowler, D., Smith, R.I., Muller, J.B.A., Hayman, G. and Vincent, K.J., 2005. Changes in the atmospheric deposition of acidifying compounds in the UK between 1986 and 2001. Environ. Pollut., $137,15-25$.

Guisti, L. and Neal, C., 1993. Hydrological pathways and solute chemistry of storm runoff at Dargall Lane, southwest Scotland. J. Hydrol., 142, 1-27.

Gundersen, P., Callesen, I. and de Vries, W., 1998. Nitrate leaching in forest ecosystems is related to forest floor $\mathrm{C} / \mathrm{N}$ ratios. Environ. Pollut., 102, 403-407.

Harriman, R., Curtis, C. and Edwards, A.C., 1998. An empirical approach for assessing the relationship between nitrogen deposition and nitrate leaching from upland catchments in the United Kingdom using runoff chemistry. Water, Air Soil Pollut., 105, 193-203.

Helliwell, R.C., Ferrier, R.C., Evans, C. and Jenkins, A., 1998. A comparison of methods for estimating soil characteristics in regional acidification models; an application of the MAGIC model to Scotland. Hydrol. Earth Syst. Sci., 2, 509-520.

Helliwell, R.C., Ferrier, R.C. and Kernan, M.R., 2001. Interaction of nitrogen deposition and land use on soil and water quality in Scotland: issues of spatial variability and scale. Sci. Total Envir., $265,51-63$.

Helsel, D. and Hirsch, R., 1991 Statistical methods in water resources. United States Geological Survey.

Hope, D., Billett, M.F., Milne, R. and Brown, T.A., 1997. Exports of organic carbon in British rivers. Hydrol. Process., 11, 325344.

Kamenik, C., Schidt, R., Kum, G. and Psenner, R., 2001. The influence of catchment characteristics on the water chemistry of mountain lakes. Arctic Antarctic Alp. Res., 33, 404-409.

Kaste, Ø., Henriken, A. and Hindar, A., 1997. Retention of atmospherically-derived nitrogen in subcatchments of the Bjerkreim River in southwestern Norway. Ambio., 26, 296-303.

Kernan, M.R. and Allott, T.E.H., 1999. Spatial variability of nitrate concentration in lakes in Snowdonia, North Wales, UK. Hydrol. Earth Syst. Sci., 3, 395-408. 
Kopácek, J., Stuchlík, E., Straškrabová, V. and Pšenáková, P., 2000. Factors governing nutrient status of mountain lakes in the Tatra Mountains. Freshwater Biol., 43, 369-383.

Kristensen, H.L., Gundersen, P., Callesen, I. and Reinds, G.J., 2004. Throughfall nitrogen deposition has different impacts on soil solution nitrate concentration in European coniferous and deciduous forests. Ecosystems, 7, 180-192.

Lovett, G.M., Weathers, K.C., and Arthur, M.A., 2002. Control of nitrogen loss from forested catchments by soil carbon:nitrogen ratio and tree species composition. Ecosystems, 5, 712-718.

Milne, J.A. and Hartley, S.E., 2001. Upland plant communitiessensitivity to change. Catena, 42, 333-343.

Mulder, J., Pijpers, M. and Christophersen, N., 1991. Water-flow paths and the spatial distribution of soils and exchangeable cations in an acid rain impacted and a pristine catchment in Norway. Water Resour. Res., 27, 2919-2928.

NEGTAP 2001. Transboundary air pollution: acidification, eutrophication and ground-level ozone in the UK DEFRA contract (EPG 1/3/153), ISBN 1870393.
Nilsson, J. and Grennfelt, P., 1988. Critical loads for $S$ and $N$. Report from a workshop held at Skokloster, Sweden March 1988, Published by Nordic Council of Ministers, Copenhagen, Report 1988:15.

Stoddard, J., 1994. Long-term changes in watershed retention of nitrogen. In: Environmental chemistry of lakes and reservoirs. L.A. Baker (Ed.), American Chemical Society.

UN-ECE, 2002. http://www.unece.org/env/lrtap

Vincent, K.J., Campbell, G.W., Downing, C.E.H., Hasler, S.E., Davies, M., Stedman, J.R., Sansom, L.E., Briscombe, C. and Page, H.M., 1997. Acid deposition monitoring in the United Kingdom: the first 10 years. Report AEAT/20017110/REMA304. AEA Technology, Culham, UK.

Watson, A., Davidson, R.W. and French, D.D., 1994. Summer snow patches and climate in northeast Scotland, UK. Arctic Alp. Res., 26, 141-151. 